\title{
Planning, Land and Housing in the Digital Data Revolution/The Politics of Digital Transformations of Housing/Digital Innovations, PropTech and Housing - the View from Melbourne/Digital Housing and Renters: Disrupting the Australian Rental Bond System and Tenant Advocacy/ Prospects for an Intelligent Planning System/ What are the Prospects for a Politically Intelligent Planning System?
}

Libby Porter, Desiree Fields, Ani Landau-Ward, Dallas Rogers, Jathan Sadowski, Sophia Maalsen, Rob Kitchin, Oliver Dawkins, Gareth Young \& Lisa K Bates

To cite this article: Libby Porter, Desiree Fields, Ani Landau-Ward, Dallas Rogers, Jathan Sadowski, Sophia Maalsen, Rob Kitchin, Oliver Dawkins, Gareth Young \& Lisa K Bates (2019) Planning, Land and Housing in the Digital Data Revolution/The Politics of Digital Transformations of Housing/Digital Innovations, PropTech and Housing - the View from Melbourne/Digital Housing and Renters: Disrupting the Australian Rental Bond System and Tenant Advocacy/Prospects for an Intelligent Planning System/What are the Prospects for a Politically Intelligent Planning System?, Planning Theory \& Practice, 20:4, 575-603, DOI: 10.1080/14649357.2019.1651997

To link to this article: https://doi.org/10.1080/14649357.2019.1651997

Published online: 02 Sep 2019.

Submit your article to this journal $\square$

Џll Article views: 1981

Q View related articles ¿ 
INTERFACE

\title{
Planning, Land and Housing in the Digital Data Revolution
}

\author{
Libby Porter
}

Centre for Urban Research, RMIT University, Melbourne, Australia

\section{Introduction}

If planning is an activity that attempts to mediate market effects in land use and resource distribution, then the revolution from digital tech is fundamentally changing the planning landscape. In sectors of core importance for planning, new platforms, smart devices and digital data are now not merely mediating, but governing relationships, capital flows and behaviours (Fields, 2019, p. 1). In conjunction with other forms of political and social change, the availability of new technologies and devices offer new opportunities for the production of data itself. This is what Kitchin (2014b) calls the 'data revolution', or how the "volume, variety, velocity, resolution, and availability of data, and how data are being processed, analysed, stored and employed to leverage insight and value is being radically transformed" (25).

This rapidly shifting technological landscape is at the same time coordinating new actors, approaches, sites and relationships for land, housing and governance. Combined with trends of intensifying financialisation, technological and digital change are amplifying the speed, scale, scope and reach of accumulation. Rolnik (2019) has shown the global reach of the international finance system right down into the homes and lives of ordinary people.

But this shifting technological landscape is more than simply the emergence of new actors or methods. As Rolnik argues, what it signifies is a "particular form of value storage, as it directly relates macroeconomics to individuals and families, and allows, through financing mechanisms, the interconnection of many central actors of the global financial system" (2019, p. 50). Nothing less, in short, than the completion of the transformation of housing from a social good to a financial asset (Rolnik, 2019, p. 47).

These trends are not limited to home ownership and mortgage systems, for rental housing has become a significant site of accumulation for private equity, hedge funds and REITs through a range of financial instruments (Aalbers, 2019). Informal housing is also increasingly imbricated into the reach of data digitisation (Luque-Ayala \& Neves Maia, 2018). As Fields argues, these "advances in digital technology have been essential to creating a new financial asset for the post-crisis era" (Fields, 2019, p. 3). It is not simply that new technologies, platforms, apps and Big Data speed up existing processes, or increase their geographical reach (though they do both of course), but that new forms of social and economic relationship are being formed through these technologies.

Recent issues of Interface have examined different dimensions and facets of this digital and data revolution. In Volume 19(5) we looked at automated vehicles and then in 20(2) and 20(3) we examined 
different dimensions of the sharing or platform economy. The contributions across these Interface issues highlighted that the invention of the App, and the proliferation of devices that make Apps useable, have turned local informal networks of 'sharing' into extraordinarily big and booming businesses.

A strikingly resonant theme across all these Interface issues is how these shifts amplify and deepen the abstraction and separation of functions, users and outputs from actual things and places. Uber, for example, coordinates over 5billion rides globally without employing a single driver. Airbnb influences a massive and global market in land and housing without ever directly investing in actual bricks, mortar or dirt (Holman, 2019). At the same time there are a mind-boggling array of PropTech and FinTech applications that are much less obvious, functioning behind larger processes or systems. These further decouple social actors from the actual time-place dimensions in which they are located. Just like the invention of Torrens titling, where the artefact of the title register itself allowed "users and the land attached to them through property to be temporally extricated from the material constrains of history" (Keenan, 2018, p. 285), these contemporary forms of technological change are further amplifying this extrication and in so doing producing new dynamics.

Regulating these rapidly changing and emerging sectors and actors is proving to be especially challenging. The decoupling of the owner of the tech from the functioning on the ground of the service or product allows large companies to absolve themselves of responsibility. The high-profile cases of Uber drivers left entirely unprotected by any kinds of workers' rights is a case in point. One especially interesting observation in the discussion on the Sharing Economy in Volume 20(2) was that regulation is challenging, especially at the local government scale, because of a lack of data (Kim, 2019). Perhaps in an increasingly data-rich world, we know less and less that is useful.

Of course, there has been considerable discussion in popular and media discourse about the implications for individual privacy, ethics and surveillance. Who is collecting this data from Apps and other processes? Who can access it? To what uses is it put and in whose interests? Recent concerns with Facebook and Google suggest that there is much more going on here than the regulation of individual data protection rights and ownership would solve. These are wide and deep questions of governance and power, as it is precisely this data which is creating new opportunities for accumulation. As the saying goes among social media users: if you are not being sold a product, you are the product. In the real estate sector, data mined from consumer and purchasing patterns is being used to predict and in some cases manipulate, shape and even govern consumer choice, and at the same time shifting behaviours of actors in land and housing markets.

This has even wider implications when situated in the context of gender, race, class and heteronormativity. As work in digital sociology and data ethics is revealing, digitisation and Big Data are facilitating further forms of social sorting and racial bias. Algorithmic analysis, whether deliberately or inadvertently, can be used to target or mark certain social groups, intensifying existing racialized patterns of both surveillance and exclusion (Eubanks, 2018).

Much has also been discussed about the impact Big Data might be having on the production of knowledge more generally. Some commentators have even suggested it heralds the 'end' of the scientific method itself (see the debate as outlined in Kitchin, 2014a). Yet just like all other kinds of data, Big Data is socially produced and intrinsically political. As Kitchin reminds us: "all data provide oligoptic views of the world: views from certain vantage points, using particular tools, rather than an all-seeing, infallible God's eye view" (2014a, p. 1). And just like all technology, PropTech is not simply a neutral technique or platform that replaces previously analogue systems. It, too, should be understood as social and political. 
In this Interface we examine the co-emergence of PropTech and Big Data, the impact on land and housing dynamics, and the implications for planning governance and systems. We invited a series of experts to consider the way that 'the digital' is changing the way we live and inhabit our cities and neighbourhoods, both in the sense of digital transformations and the Big Data that such digitisation produces. What do these changes mean? Whose interests are served? What kinds of social relationships do they break or forge anew? How do they affect different social groups, their rights and responsibilities and in what ways? Read together with our previous Interface issues on automation and the platform economy, this Interface offers important insights into the implications for planning in the age of the digital and data revolution.

The first three essays provide different views on and understandings of the transformation unleashed on housing and dwelling patterns by digitisation. Desiree Fields sets the scene, providing a critical overview of how to understand PropTech as a phenomena before giving some in-depth insights through a series of applications that are producing material social bias in US housing markets. Landau-Ward and Porter draw on current research examining the emergence of a range of PropTech applications and the influence they are exerting on the severe affordable housing crisis in Melbourne. Rogers, Sadowski and Maalsen look more closely at similar trends of digital housing on the rental bond system in Sydney, and how this is affecting tenant rights and advocacy. Shifting the focus to the Big Data that such applications among other processes and structures produce, Kitchin, Dawkins and Young present a discussion from their research to develop an 'intelligent planning system' in Ireland and the barriers and challenges from a Big Data perspective that such a project entails. Partially responding to that essay, Lisa Bates presents research from Portland US showing how the availability of data is a primary problem for equity planning, precisely because such data is owned by private real estate companies. Together, the contributions suggest that the impact of the digital revolution on housing holds major implications for planning.

\section{Notes on contributor}

Libby Porter is Professor of Urban Planning at RMIT University. Her research is focused on dispossession and displacement as a result of urban policy and development with regard to Indigenous rights, public housing, urban renewal and critical property studies. Email: Libby.porter@rmit.edu.au

\section{References}

Aalbers, M. (2019). Financial geographies II: Financial geographies of real estate and housing. Progress in Human Geography, 43, 376-387.

Eubanks, V. (2018). Automating inequality: How high-tech tools profile, police, and punish the poor, New York: Macmillan Press.

Fields, D. (2019). Automated landlord: Digital technologies and post-crisis financial accumulation. Environment and Planning A, doi:10.1177/0308518X19846514.

Holman, N. (2019). Regulating platform economies in cities - disrupting the disruption? Planning Theory and Practice, 20(2), 271-274.

Keenan, S. (2018). From historical chains to derivative futures: Title registries as time machines. Social and Cultural Geography, 9365, 1-21.

Kim, A. J. (2019). Planning and the so-called 'sharing' economy. Planning Theory and Practice, 20(2), 261-263.

Kitchin, R. (2014a). Big data, new epistemologies and paradigm shifts. Big Data \& Society, 1(1), 1-12. 
Kitchin, R. (2014b). The data revolution: Big data, open data, data infrastructures and their consequences. London: SAGE.

Luque-Ayala, A., \& Neves Maia, F. (2018). Digital territories: Google maps as a political technique in the re-making of urban informality. Environment and Planning D: Society and Space, 37(3), 449-467.

Rolnik, R. (2019). Urban warfare: Housing under the empire of finance. New York: Verso.

\section{The Politics of Digital Transformations of Housing}

\section{Desiree Fields}

Department of Geography, University of California, Berkeley, CA, USA

The advances associated with Tech Boom 2.0 - including cloud and mobile computing, digital platforms, and automated, data-driven decision-making tools - are dramatically reshaping how housing is bought and sold by homeowners and investors (Casselman \& Dougherty, 2019), operated by landlords (Fields, 2019) and inhabited by us all (Maalsen \& Sadowski, 2019). New technologies from the early 17 th century invention of the surveyor's chain to the digitization of real estate practice enabled by so-called property technology, or 'proptech' - inevitably reshape how we "practice ownership, use, and exchange of the earth" (Shaw, 2018, p. 6). And no wonder: in advanced economies the value of the residential real estate sector is substantial - just over $\$ 27$ trillion in the US in 2018 (Housing Finance Policy Center, 2019). Yet the industry has been slow to adopt proptech (what Shaw, 2018 terms "platform real estate"), making it ripe for 'disruption' by venture capital-backed startups, along the lines of the impact that ridehailing platforms like Uber have had on the taxi industry.

It is vital to embed the digital transformations of housing, promised by platform real estate, within their wider contexts, and to interrogate their consequences and whose interests they serve. As digital platforms intervene in housing markets, they are both transferring 20th century mechanisms of racialized exclusion into 21 st century technologies, and actively shaping content in ways that can (and do) mimic calculated discrimination. Without an explicit focus on housing justice, platform real estate is likely to serve the interests of people and places already benefiting from property-led accumulation, undermining the interests of property-less subjects and marginalized places.

\section{Facebook, Disparate Treatment, and Disparate Impact}

The history of housing in the United States is inseparable from systematic, finance-mediated underdevelopment of Black geographies. The dual housing market forged in 20th-century America "conflated blackness with economic risk and deteriorating property values," producing racialized geographies in order to extract value (Taylor, 2012, p. 202). This segregation subsequently enabled predatory lending to Black borrowers in the lead-up to the 2008 crisis (Rugh, Albright, \& Massey, 2015). The ability for housing and mortgage advertisers to use Facebook to exclude specific groups (a capability the platform has now limited) points to how digital technologies can actively enable the persistence of these processes.

A 2019 lawsuit brought by the US Department of Housing and Urban Development (HUD) against Facebook alleges the social media giant's Ads Manager platform - widely used by mortgage lenders, real estate agents, and real estate listing services - facilitates violations of the Fair Housing Act (FHA). A signal achievement of the civil rights movement, the FHA outlaws 
housing market discrimination against members of protected classes. ${ }^{1}$ According to the government's complaint (US Department of Housing and Urban Development, 2019), Ads Manager enables advertisers to target what kinds of Facebook users will (not) see an ad according to user attributes that correspond to protected classes, such as "Hispanic Culture," "single moms,", and "Christian". Yet such discriminatory personalization is largely invisible, attesting to Laura Forlano's (2018) argument that contemporary technologies "act on our biases by replicating them and distributing them into the background of everyday life, thereby reinforcing and even exacerbating existing structural inequalities" (np).

But platforms do not only transmit social bias. Despite framing themselves as neutral conduits (Gillespie, 2010), platforms are more than utilities facilitating the interaction of, say, landlords and prospective tenants. Defining features of platform technology can also create new modes of inequality. Data collection is an inescapable condition of using platforms: the content of posts, clicks, likes, and reposts, and even how long a user pauses while scrolling through a news feed, all provide data points for platform operators. The information people share as they interact on Facebook is deeply valuable because of how it supports targeted advertising; it is also central to how Facebook can actively shape disparate housing market experiences that reinforce existing patterns of advantage and disadvantage. The platform economy giant constitutes a crucial piece of what Fourcade and Healy (2017) term the "information dragnet," by which stores of data are amassed, enabling the "process of sorting and slotting people" (14) to extract profits. Such classificatory systems also reflect structural biases in society and involve issues of control over and access to information, (mis)representation, and inclusion and exclusion (Noble, 2018).

Ads Manager relies on Facebook users' "sharing" to generate data on their attributes and behavior, which is subjected to predictive analytics to classify users and their likelihood of engaging with a given ad. These categories are the basis for creating eligible audiences for ads, selecting the users who actually view ads, and differentially pricing ads according to the groups that view them (e.g., charging more for the same ad to show up in the feed of women versus men). Facebook will not show ads to users deemed unlikely to engage, even if the advertiser wants them to see it. HUD's lawsuit (2019) argues that because pages visited and liked, apps used, and purchasing habits all vary in identifiable ways according to protected class, Facebook's targeted advertising "inevitably recreates groupings defined by their protected class" (5). As a result, it may produce housing market outcomes indistinguishable from intentional discrimination; for example by systematically showing members of protected classes adverts for more costly loan products - thereby carrying economic punishment.

The suit against Facebook reveals how platforms can both serve as avenues of disparate treatment by landlords, real estate agents, and lenders, and automate housing market inequalities through how opportunities are (not) made visible.

\section{Tourists Vs. Tenants: The New Dual Housing Market?}

Short-term rental platform Airbnb provides another illustration of how platforms contribute to housing inequality. Not long before HUD's case against Facebook, the city of New York sued Metropolitan Property Group, accusing the brokerage of using fake Airbnb host accounts to operate illegal hotels. The individuals named in the suit legally leased apartments in dozens of buildings, listed them on Airbnb under profiles that looked like typical hosts, and created 18 
corporations to route the income generated to themselves. The scheme generated over $\$ 20$ million in revenue before the city's recent crackdown. This case points to how Airbnb, itself notorious for skirting regulations (such as zoning rules against hotel lodgings in residential areas) and taxes (including hotel taxes), also facilitates illegal behavior.

More compelling though, is what the case shows about how platform dynamics spill over into local housing markets. Airbnb was initially touted as a way for people to earn a bit of extra money by renting out ("sharing") a spare room or their home while they were out of town. But the imperative to up-scale - to "rapidly and consistently add users," is at the centre of the platform business model (Langley \& Leyshon, 2017, p. 11) For Airbnb, this means more and more listings, especially for entire homes, coming on to the platform, and those listings being available more consistently than would be allowed by hosts renting out homes during the odd trip out of town. Drawing ever-increasing numbers of rooms or properties onto Airbnb draws them out of what must now be called the long-term rental market, to distinguish it from the short-term rental market the platform has created and normalized.

The higher revenues to be earned from renting properties to tourists and travelers rather than to tenants, along with the lower legal/regulatory burden, have spawned commercial-scale Airbnb operators with multiple listings (and the fraud tactics discussed above). In New York, Airbnb has removed thousands of rental units from the market for city residents, and is responsible for about 16 percent of the city's increase in rent between 2014 and 2017 (Wachsmuth, Chaney, Kerrigan \& Shililo, 2018). The growth of entire-home listings was especially high in predominantly Black and Latinx neighborhoods subject to gentrification pressures (such as Bedford-Stuyvesant), where the difference between the rents of long-time residents and potential Airbnb income was greatest (Wachsmuth \& Weisler, 2018). The resulting loss of housing coupled with the rent increases are more likely to affect Black residents, while hosts in such neighborhoods - and therefore the economic beneficiaries of this process - are predominantly white (Cox, 2017).

In the case of platforms like Airbnb, the rush to 'scale' creates new speculative opportunities for property owners, and affects housing opportunities by pitting tenants against tourists. But this process also maps onto existing patterns of racialized capital accumulation via the housing market, in which communities of color are destabilized for the economic benefit of white landlords.

\section{Digitizing Housing Justice}

Digital platforms can clearly work to reinforce social and spatial hierarchies of housing (dis) advantage, and reproduce ideology that privileges homes as vehicles for speculation. In addition to 'uploading' long-standing strategies of racial and social exclusion, core features of platform operation (such as data collection, classification, and up-scaling) serve as novel mechanisms of housing inequality, albeit mechanisms that only work because of structural injustices within the US housing market.

Rather than embracing a dystopian technological determinism that forecloses progressive digital transformations of housing, we must look to movements that are using platforms and other tools of Tech Boom 2.0 to support long-standing struggles for housing justice. This includes the Housing Data Coalition, which uses New York City public data to create tools such as 'Who Owns What' to demystify property ownership, and "Justfix.nyc" to support tenant 
rights; the Anti-Eviction Mapping Project's digital storytelling about dispossession and narratives of resistance made with community partners in San Francisco, Los Angeles, and New York; and 'Wem Gehört Berlin' (Who Owns Berlin), which crowdsources data from tenants to document property ownership and investment patterns. By looking at how platform technologies are used from and for the margins, it is possible to generate more radical urban futures.

\section{Acknowledgements}

The author wishes to thank Public Books for permission to republish a version of this essay. The original essay may be accessed at: https://www.publicbooks.org/uploading-housing-inequalitydigitizing-housing-justice/

\section{Notes on contributor}

Desiree Fields is an urban and economic geographer based at the University of California, Berkeley. Her work examines financial and technological transformations of housing, the urban struggles that cohere around these processes, and pathways toward housing justice. Email: desireefields@berkeley.edu

\section{References}

Casselman, B., \& Dougherty, C. (2019, May 9). Real estate's latest bid: Zillow wants to buy your house. The New York Times, Retreived from https://www.nytimes.com/2019/05/07/business/economy/ibuying-realestate.html.

Cox, M. (2017). The face of Airbnb, NYC: Airbnb as a racial gentrification tool. Inside Airbnb, Retrieved from http://brooklyndeep.org/wp-content/uploads/2017/03/the-face-of-airbnb-nyc.pdf.

Fields, D. (2019). Automated landlord: Digital technologies and post-crisis financial accumulation. Environment and Planning A: Economy and Space, doi:10.1177/0308518X19846514.

Forlano, L. (2018). Invisible algorithms, invisible politics. Public Books, Retreived from https://www.public books.org/invisible-algorithms-invisible-politics/.

Fourcade, M., \& Healy, K. (2017). Seeing like a market. Socio-Economic Review, 15(1), 9-29.

Gillespie, T. (2010). The politics of 'platforms'. New Media \& Society, 12(3), 347-364.

Housing Finance Policy Center. (2019, April). Housing finance at a glance: A monthly chartbook. Washington, D.C.: The Urban Institute.

Langley, P., \& Leyshon, A. (2017). Platform capitalism: the intermediation and capitalisation of digital economic circulation. Finance and Society, 3(1), 11-31.

Maalsen, S., \& Sadowski, J. (2019) The smart home on FIRE: Amplifying and accelerating domestic surveillance. Surveillance \& Society, 17(1/2), 118-124.

Noble, S. U. (2018). Algorithms of oppression: How search engines reinforce racism. New York: NYU Press.

Rugh, J. S., Albright, L., \& Massey, D. S. (2015) Race, space, and cumulative disadvantage: A case study of the subprime lending collapse. Social Problems, 62(2), 186-218.

Shaw, J. (2018). Platform real estate: theory and practice of new urban real estate markets. Urban Geography, doi:10.1080/02723638.2018.1524653.

Taylor, K.-Y. (2012). Back story to the neoliberal moment: Race taxes and the political economy of black urban housing in the 1960s. Souls, 14(3-4), 185-206.

US Department of Housing and Urban Development. (2019). HUD v Facebook. Retrieved from https://www. hud.gov/sites/dfiles/Main/documents/HUD_v_Facebook.pdf

Wachsmuth, D., \& Weisler, A. (2018). Airbnb and the rent gap: Gentrification through the sharing economy. Environment and Planning A: Economy and Space, 50(6), 1147-1170. 
Wachsmuth, D., Chaney, D., Kerrigan, D., \& Shililo, A. (2018). The high cost of short-term rentals in New York City. School of Urban Planning, McGill University, Retrieved from https://davidwachsmuth.com/2018/02/ 01/the-high-cost-of-short-term-rentals-in-new-york-city/

\section{Digital Innovations, PropTech and Housing - the View from Melbourne}

Ani Landau-Ward and Libby Porter

Centre for Urban Research, RMIT University, Melbourne, Australia

The collection, digitisation and use of housing information in Australia has increased exponentially in the past decade. This brings significant implications for land and housing law and governance. The move from 'analogue' to digital, then to big data and Artificial Intelligence (Ai) not only speeds up existing social, economic and political relations, but fuels new and different dynamics (Kitchin 2014, pp. 19-20) just as innovations such as the printing press or telephone did in the past. As such, emerging digital and informational geographies and politics demand renewed critical attention (Dalton, Taylor, \& Thatcher, 2016).

As in many other cities, the proliferation of these technologies is occurring in a context of housing crisis where land prices are escalating and producing significant housing unaffordability. The confluence of these factors highlights the importance of examining the urban governance implications of the emergence of what is often termed 'Prop-Tech' (Shaw 2018) - new technological applications in real estate. Greater understanding of PropTech is vital to sharpen the legal and policy response to the emergent urban governance aspects of digitisation. In this essay, we present results from an initial scoping study into the proliferation of these technologies in Melbourne, Australia.

Three aspects are important for considering the governance implications of PropTech. First, PropTech increases the sheer amount of recorded information about land, housing, and property. Second, data digitisation has specific effects, such as the emergence of digital data as assets with value in and of themselves, and as data amenable to algorithmic analysis. Third, PropTech brings new actors, products, and services into housing and real-estate sectors. Most land registers in Australia have, in the past two decades, been fully digitised and many are now either partially or fully privatised (on Victoria's recent sale see Willingham, 2018). A move to e-conveyancing has digitised the entire legal process of sale and transfer of land. This is supported by a Federal Government initiative to secure a national (and privatised) system of property transfer termed 'Property Exchange Australia' (PEXA) which is now also a listed company owned by, among others, two major banks (Duran, 2018; PEXA, 2019). Alongside these increasingly privatised stores of property-related information are other spatial datasets, such as those offered by the Australian Urban Research Infrastructure Network (AURIN), who make available an ever increasing range of fine grained information about land, property, and housing trends and behaviours, available to governments, private industry, researchers, students, and the public (AURIN, 2019). 


\section{The Housing Context in Melbourne}

Melbourne is experiencing significant population increase and urban densification, in relation to its history as a dispersed, low-density city. It is also, according to one popular cost of living index, in the top 100 of the most expensive cities to live in in the world (Numbeo, 2019). The landscape of housing in Melbourne is dominated by private ownership and freehold title. Yet this is now shifting from the predominant form of dwelling in privately owned detached homes with affordable mortgages, towards townhouse and apartment living and more private rental (ABS, 2016). Strata titles have increased and some researchers and advocates have called for understanding the large numbers of 'mum and dad' investors as business owners, and in the business of housing provision (Hulse, Martin, James, \& Stone, 2018). Overall, increased rental tenure, declining affordability and an increase in housing precarity and homelessness are all part of the new housing terrain (ABS, 2016; Hulse, Morris, \& Pawson, 2018).

While rental is increasing as a tenure type in the housing landscape, rental housing is still considered transitional or temporary - a step on the path toward home ownership. Significant demographic trends have been noted with people under 35 much less likely to own homes than in previous decades, and low income residents living in areas with greatly increased transportation costs and poor access to areas of high employment, meaning that some residents who do own homes are likely to be servicing unaffordable mortgages (Raynor, Dosen, \& Otter, 2017). Homelessness and housing insecurity has burgeoned, and across housing types an increasing number of people live under housing stress (Raynor et al., 2017, pp. 11-15). Many advocates, researchers and policy actors call for renewed attention to public housing, given that the state has been in active retreat from public housing for decades. This trend is intensifying through a current program in Melbourne of 'public housing renewal' (Kelly \& Porter, 2019). Public housing is being transferred to social enterprises or not-for-profit organisations and providers, and there is consensus across policy and housing advocacy groups that public housing is in woefully inadequate and declining supply, and utterly unable to meet the scale of housing crisis (Tenants Union, 2015).

Housing for the most disadvantaged in Melbourne has to be sourced in the cracks and margins - in cars, caravan parks, house-less camps, in overcrowded, or subdivided apartments, or on couches (Moore, 2017). At the same time, the crisis housing sector has become so disillusioned with the state of short-term emergency shelter options, they have recently told the Victorian Government that they will refuse to send people experiencing homelessness to shelters because the shelters are worse than being homeless (North and West Homeless Networks 2019).

\section{Emerging PropTech in Melbourne}

In Melbourne, companies such as CoreLogic have tapped a lucrative business opportunity in analysing records, valuations, sales and transfers on a database that boasts "4 billion property decision points". They market themselves as "the largest provider of property information, analytics and property-related risk management services in Australia and New Zealand" (CoreLogic, 2019). This shifting landscape is not only about large private corporations, as social enterprises are also increasingly part of the mix. These often have the ostensibly more laudable aims of matching social services and utilising digital platforms for the digital public good. The most important of these in the housing domain is probably Ask Izzy, a not-for-profit social 
enterprise powered by the giant Info-Exchange, and supported by: transnational tech giant Google; real estate giant REA group; and media giant News Corp. Ask Izzy is marketed as an open data platform that offers a range of tools to connect those seeking social services, including housing and healthcare, to providers of various kinds. These are not just government and social service providers but range from homeless shelters to private hotels. When we conducted our search for this paper, the search returned properties belonging to the lbis hotel group. They also claim to utilise Australian Bureau of Statistics (ABS) data and Australian Institute of Health and Welfare (AIHW) data to provide "insights into the supply and demand of services across Australia such as housing, food, health and more" (Ask Izzy, 2019).

This newly data rich environment is further catalysing a range of new real estate related products and services that utilise information in new ways for commercial purposes. These are generally operated by what have lately come to be known as 'platform' companies. In Melbourne there is great diversity in the PropTech space, from hopeful startups, whose online presence may look impressive, but are in fact small and risky, to large scale coordinated operations with huge investors taking up serious market share and expanding into extensive areas of real estate, property, and housing. The biggest players in Melbourne are the international giants REA group and Domain.com who have both invested heavily in numerous new PropTech products. Like other platform entities, they have various partnerships with other products, such as the relationship between Flatemates.com.au and the REA group.

There are also a range of ways that such Apps and tech link or connect into other sectors, especially finance and banking. Experimental startups, like Land LayBy Australia, facilitate the sale of future land options in Kenya from Australia, and are developing a privately owned, blockchain land registration system (in Kenya), that they plan to use to secure these options. (Land LayBy, 2019). There are also a range of small, new fractionalised investment platforms such as:

- BrickX who allow investors to buy any number of shares (bricks) in any number of properties that the platform manages;

- DomaCom which enables investors to pool money to buy property, or to invest in a range of properties. This App utilises both 'crowdfunding' and peer to peer (p2p) techniques, and now targets elderly home owners to provide 'equity release' through selling off fractions of their homes;

- CoVesta which was designed as a platform tool to enable multiple buyers to invest in a property that is rented out and sold after 5 years, but in its current iteration sells its platform tool as a product for those looking to arrange investments for their own clients; and

- Estate Baron which offers fractionalised co-investment opportunities and (with other influential real estate and developer interests) is building a blockchain (an enabled, distributed registry) where fractionalised shares in land and property interests, or other securities, can be registered. Called KonKrete, it is expected to come online soon (KonKrete, 2019)

Other PropTech applications are closely associated with fintech and real estate sales. For example, the price prediction software REALas, owned by the ANZ bank, claims to have designed "the smartest property price prediction service in Australia" (REALas, 2019). There are 
many other applications and platforms that provide other financial services related to housing, such as insurance, loans and applications.

PropTech is not just confined to the various ways that property can be bought and sold. It is increasingly used in the range of services, and products associated with both long-term and shortterm rental tenancies. At a recent conference on digital disruptions and housing policy, the chief economist for the REA group Nerida Cosbee shared a list of at least 50 platforms and businesses that she saw as disrupting the residential rental sector in the coming twelve months, calling them "renttech" or "rent-focused" PropTech in a "universe of prop tech businesses" (Cosbee, 2018). The most obvious of these are the big platforms that have disrupted hotels, such as Airbnb, or Booking.com, but there are others that cross over more with other traditional rental and real estate sectors. Rent. com.au, for example, is a private company listed and founded in 2016 with major shareholders a mix of private individuals and investment firms such as HSBC. It aspires to be "a one stop shop for the rental industry", and claims that growing numbers are choosing renting as a "lifestyle and investment" choice (Rent.com.au, 2019). Rent.com.au products expand well beyond older matching services and include: RentCheck; RentBond; RentConnect; RenterResume; RentPay; and RentQuote. It also markets insurance products and is affiliated with commercial leasing platform Lease.com.au. Another PropTech platform, Equiem, who have offices in Melbourne, London and New York, focuses on landlord experience, claiming that they "exist to help landlords unlock new value in their assets" (Equiem, 2019).

More facilitation focussed products have exploded in recent years. Services and products related to rental tenures have become lucrative opportunities for identifying new markets, especially in a context like Melbourne where rental share of the housing market is growing. The PropTech platforms and applications moving into rental tenure are diverse. Bricks +Agent, for example, is "a cloud based marketplace for homeowners and trade professionals to list, discover and connect with one another to complete property maintenance jobs" (Bricks+Agent, 2019). It also coordinates house inspections. Rex Software, is a cloud based real estate customer relationship management (CRM) system that provides software to manage and analyse diverse aspects of the real estate business, focused on interactions with various types of clients. It claims, for example, to be the "single point of truth for every client" and it "stores a rich tapestry of relationships individuals have with other properties or contacts, and a comprehensive stream of every interaction they've had with any other user in your agency" (Rex Software, 2019). Leaselnfo, a leasing data provider, released Accurait last year, a cloud-based software that uses artificial intelligence and machine learning methods for "saving time in a document-intensive commercial lease management environment" (Tan, 2018). Finally, Activepipe, whose main business is to automate and curate messaging and communication between real estate agents and clients (both landlord and tenant), works by analysing data by Ai algorithm. Melbourne-based but active Australia wide, in the last 12 months it has secured three Australian business awards and successfully completed a $\$ 5.9$ million funding drive.

\section{Impacts and Trends}

There is often an assumption that the digitisation of land and housing information, and the emergence of PropTech, are inherently neutral, or even inherently good. The belief that more data, more information, and more efficient use of it, will intrinsically benefit society, especially 
through enhancing technical knowledge and making older processes quicker, smoother, and easier seems an unshakeable faith. In our analysis of the technological disruptions in Melbourne, this is often focused on the range of potential efficiencies digital disruptions might create - for example enabling better matching between consumers and housing, or speeding up and reducing the cost of transactions (eg: Pettit, Crommelin, Sharam, \& Hulse, 2018; Sharam, Byford, Karabay, McNelis, \& Burke, 2018).

Consequently, much of the debate about the ethical aspects of digitisation is focused on questions of privacy, transparency, openness and ownership of what is ultimately considered neutral and individual data. This maintains a conception of the data as somehow apolitical, and does not engage with the ways such data is being shaped in the interests of those who control it, or the ways that certain demographics may be positioned differently to others in regard to how they are represented or "seen" in the data (Crawford, Gray, \& Miltner, 2014). We argue that these digital disruptions cannot be viewed as simply neutral technologies that replace existing analogue processes, but are instead fundamentally social and political processes entwined with existing and emerging power relations (Kitchin 2014, p. 19-20; Dalton et al., 2016; Shaw \& Graham, 2017; Taylor \& Richter, 2015). As Crawford and colleagues note, "data sets are not, and can never be, neutral and theory-free repositories of information waiting to give up their secrets" (2014, p. 8). Paying attention to questions such as who benefits? and who loses? as the technologies are taken up across city neighbourhoods - as well as to which experiences and perspectives on housing are diminished, erased or made invisible? is urgent and important.

As we have shown in relation to Melbourne, various PropTech products are enabling the movement of private rental tenancy management to online Apps where applications, bonds, and matching services occur online often achieved through Ai augmented decision-making. At the same time, a growing number of platforms foster linkages between social and public housing, homelessness services, and private real estate companies, creating stores of information that potentially complicate traditional divides between public and private. While many may seem like exciting opportunities to enable greater access to housing services, we must also remember how information about housing, and housing users, is being leveraged and capitalised in new ways. As the CEO of real estate software giant Altus Group stated:

This is a data game ... The world of real estate is driven by demographics and generational changes, the risk in assets, type of investors, and lower yields ... it has become a technology game (Tan, 2017).

PropTech and the big data about individual houses and households is not only an asset in and of itself, it helps create new kinds of financial assets. The actors with interests in these technologies often collate and store large amounts of information about housing, and resident needs including use, tenancies types and histories, tenancy applications and rejections, transactions and preferences. As such they produce new and different types of data. And, as in many other kinds of sharing applications, users occupy a position not only as consumers, but also producers of data assets and other kinds of value (Fuchs, 2017). We are only just beginning to understand these uses and their impacts on housing. Some recent research has shown how PropTech has enabled the extraction of new kinds of income flows and financial value for large scale investors in rental housing in the USA who purchased geographically dispersed property portfolios after the 'global financial crisis' (Fields, 2019). As such, the capacity for PropTech to link housing into volatile and remote financial markets is in need of inquiry, especially in the context of the global financialisation of housing (Aalbers, 2016).

The capacity of PropTech to match property owners with much bigger and more specific markets has also catalysed other significant transformations. One of these has been a diffusion 
among real estate actors of short-term tenancies, where previously regulatory compliance, administrative, and matching costs forced a more consolidated, and centralised set of actors. The most well-known PropTech platform in this space is Airbnb who are well known for 'disrupting' the hotel business, as well as for battling local regulators both through their hosts, and in court, and stubbornly resisting responsibility for ensuring hosts comply with local laws (Martineau, 2019). Airbnb has been widely studied in the Australian context (see: Gurran, 2018). But many other platforms engage in similar, or more housing focussed aspects of short term tenure. Flatmates. com for example calls itself "Australia's biggest share accommodation website" and crosses the line between traditional real-estate services and sharing economy innovations. It allows people to list their spare rooms, find accommodation themselves, or team up with other people to rent a place or start a share house. The Melbourne based company has steadily grown from humble beginnings to the point of claiming in 2016 to have $60 \%$ of market share, and 2.8 million visits in a month, also the year it joined Australia's biggest provider of online real estate services, REA group. While flagging compliance with local laws and regulations on its website, Flatmates.com, like Airbnb (where it can), ultimately leaves this to the responsibility of users (Flatmates.com 2019).

While having obvious advantages for some and potentially making short term tenancies more accessible, this proliferation of new arrangements may nonetheless increase the scale of precarious and insecure housing stock as at least some owners wait for lucrative short term tenancies rather than rent to longer term tenants (see Gurran, 2018; Gurran \& Phibbs, 2017). It may also potentially foster the capacity to discriminate and sort potential tenants which, as these forms of housing access become more ubiquitous, becomes more pressing to address. Facebook for example is currently being sued by the US government's Housing and Urban Development agency (HUD) for allowing advertising for housemates and tenants to restrict the reach of their housing advertisements based on race, religion or national origin (see Fields this issue).

Beyond these forms of overt discrimination, Virginia Eubanks has shown how inequality can be automated. Her analysis in the US reveals that the automation of housing decisions, including the operation of homeless and social service programs, "profile, police, and punish the poor" (Eubanks, 2018). Henman (2018) has found similar issues with algorithms behind government services in Australia, stating that certain populations may be increasingly "segmented, fragmented, or controlled" (p. 71). More generally algorithms and search engines, such as those increasingly built into PropTech and other aspects of the digitisation of housing information, have been shown repeatedly to have the capacity to learn and reproduce racism, and other forms of discrimination (Noble 2018).

Discrimination and bias in the housing sector, particularly in rental markets, has of course always been a significant problem. Rather than accuse new technologies of starting it, we must ask how they might reproduce and reorganise it. Moreover, just as data is not inherently neutral neither is it inherently regressive. Many aspects of housing data are of genuine use to housing advocates and able to serve as a social good, as demonstrated by movements such as the AntiEviction Mapping Project (2019) who even use tech to map the displacement of residents by Airbnb; or the Indigenous Data Sovereignty (IDS) movement in Australia that critically interrogates questions of consent and collective capacity to choose the way data is used and disseminated (Kukutai \& Taylor, 2016). However, neutral or positive effects are not a foregone conclusion, which suggests that it is advocacy across the sector, rather than merely the regulation of particular technologies or privacy requirements, where significant effort is needed.

The rapid pace of these changes, and the sheer scope of digital innovations and transformations, mean that housing professionals and experts alike are often at risk of being 'left behind', especially in 
regard to bigger questions concerning the ethical and social dimensions of such transformations. A number of issues are immediately clear. First, is that there needs to be a shift towards differentiating housing from real estate. Digital disruptions in housing demonstrate clear trends toward the intensification of commodification of housing, precisely at a time when the limits of that commodification have been laid bare. Second, a policy and legal framework is necessary that conceptualises housing and its associated data, not as product but as home. Some small inroads have certainly been made toward this in Victoria, on the back of significant civil society action, such as recent changes to the Residential Tenancies Act (Vic) but there is much more work to do. Connections need to be made between the lived experiences of housing that are witnessed by these groups, and the structures of access and tenure being fostered in these platforms. Third, the governance solutions, and interventions necessary in this shifting digital landscape, must transcend questions of individual privacy, specific domains or uses. This will involve creating new accountabilities and responsibilities for providers of the diverse range of commercial products and services around housing. All are questions in need of further research and practice engagement.

\section{Acknowledgements}

We acknowledge the Woiwurrung and Boonwurrung speaking peoples of the Kulin Nation on whose unceded lands this essay was written. This essay is part of a larger study of digital disruption in the housing sector in Melbourne. The authors would like to acknowledge project collaborators Rebecca Leshinsky and Paul Battersby.

\section{Funding}

The research was funded by RMIT University's Urban Futures program.

\section{Notes on contributor}

Ani Landau-Ward is a PhD scholar in the Centre for Urban Research at RMIT University. Her current research is focussed on histories and techno-politics of land administration in global development. She teaches in the Bachelor of Arts: International Studies, RMIT, and has published in the fields of public administration, urban geography, and global studies. Email: Ani.landau-ward@rmit.edu.au

\section{References}

Aalbers, M. B. (2016). The financialization of housing: A political economy approach. London: Routledge. ABS. (2016). Australian bureau of statistics 2016 census. Retreived from https://www.abs.gov.au/Housing. Anti-Eviction Mapping Project. (2019). Retrieved from https://www.antievictionmap.com/tech Ask Izzy. (2019). Retreived from https://askizzy.org.au/about

AURIN. (2019). Who Benefits from AURIN. Retrieved from https://aurin.org.au/about-aurin/the-aurinjourney/

Bricks+Agent. (2019). Retrieved from https://www.bricksandagent.com/

CoreLogic. (2019). Retrieved from https://www.corelogic.com.au/about-us

Cosbee. (2018). Chief economist REA group keynote. Disrupting the housing market conference. Hotel Grand Chancellor. Hobart, Tasmania. Tuesday 4th of December 2018. Retrieved from https://www.ahuri. edu.au/events/recent-events/disrupting-the-housing-market 
Crawford, K., Gray, M. L., \& Miltner, K. (2014). Big data| critiquing big data: Politics, ethics, epistemology| special section introduction. International Journal of Communication, 8, 1663-1672.

Dalton, C. M., Taylor, L., \& Thatcher, J. (2016). Critical data studies: A dialog on data and space. Big Data \& Society, 3(1), 1-9.

Duran, P. (2018, November 6). Update 2: Australia's PEXA agrees to sale at almost third below IPO value. Reuters Funds News, Retreived from https://www.reuters.com/article/pexa-ma-cba/update-2-australiaspexa-agrees-to-sale-at-almost-third-below-ipo-value-idUSL4N1XG6M0

Equiem. (2019). Retreived from https://www.equiem.com.au/about-us

Eubanks, V. (2018). Automating Inequality: How high-tech tools profile, police and punish the poor. London: St Martins Press.

Fields, D. (2019). Automated landlord: Digital technologies and post-crisis financial accumulation. Environment and Planning A: Economy and Space, doi:10.1177/0308518X19846514.

Flatemates.com. (2019). Retreived from https://flatmate.com/terms

Fuchs, C. (2017). Social media: A critical introduction. London: Sage.

Gurran, N., \& Phibbs, P. (2017). When tourists move in: How should urban planners respond to Airbnb? Journal of the American Planning Association, 83(1): 80-92.

Gurran, N. (2018). Global home-sharing, local communities and the Airbnb debate: A planning research Agenda. Planning Theory \& Practice, 19(2), 298-304.

Henman, P. (2018). Of algorithms, Apps and advice: digital social policy and service delivery. Journal of Asian Public Policy, 12(1), 71-89.

Hulse, K., Morris, A., \& Pawson, H. (2018). Private renting in a home-owning society: Disaster, diversity or deviance? Housing, Theory and Society, 36(2), 167-188.

Hulse, K., Martin, C., James, A., \& Stone, W. (2018). Private rental in transition: institutional change, technology and innovation in Australia. AHURI Final Report No. 296, Melbourne: Australian Housing and Urban Research Institute Limited.

Kelly, D., \& Porter, L. (2019). Understanding the assumptions and impacts of the public housing renewal program, centre for urban research. Melbourne: RMIT University. Retrevied from https://cur.org.au/cms/wp-content/ uploads/2019/05/understanding-the-assumptions-and-impacts-of-the-phrp-final-report-28-5-19.pdf

Kitchin, R. (2014). The data revolution: Big data, open data, data infrastructures and their consequences. London: Sage.

KonKrete. (2019). Retrieved from https://www.konkrete.io/

Kukutai, T., \& Taylor, J. (eds). (2016). Indigenous data sovereignty: Towards an Agenda. Centre for Aboriginal Economic Policy Research, Research Monograph No. 38. Canberra: Australian National University Press.

Land LayBy. (2019). Retrieved from http://www.landlayby.com.au/

Martineau. (2019, March 20). 'Inside Airbnb's 'Guerrilla war' against local governments. Wired Business. Retrieved from https:/www.wired.com/story/inside-airbnbs-guerrilla-war-against-local-governments/

Moore. (2017). Couch surfing limbo: Legal, policy, and service gaps affecting young couch surfers and couch providers in Melbourne's west. West Justice. Retrieved from https://www.westjustice.org.au/cms_ uploads/docs/westjustice-couch-surfing-limbo-report.pdf

Noble, S. U. (2018). Algorithms of oppression: How search engines reinforce racism. New York: New York University Press.

North Western Homeless Networks. (2019). A crisis in crisis: The appalling state of emergency accommodation in Melbourne's North and West. North and West Homeless Networks, Retrieved from http://www.nwhn.net.au/ admin/file/content2/c7/A\%20crisis\%20in\%20crisis\%20doc\%20final\%20040219_1550142202053.pdf

Pettit, C., Crommelin, L., Sharam, A., \& Hulse, K. (2018). The potential of new technologies to disrupt housing policy. AHURI Final Report No. 308, Melbourne: Australian Housing and Urban Research Institute Limited.

PEXA. (2019). Retrieved from https://www.pexa.com.au/company/\#about-pexa-company

Raynor, K., Dosen, I., \& Otter, C. (2017). Housing affordability in Victoria. Parliamentary Library \& Information Service, Melbourne: Parliament of Victoria.

REALas. (2019). Retrieved from https://realas.com/

Rent.com.au. (2019). Retrieved from https://www.rent.com.au/about_us

Rex Software. (2019). Retrieved from https://www.rexsoftware.com/features/contact-management/ 
Sharam, A., Byford, M. C., Karabay, B., McNelis, S., \& Burke, T. (2018). Matching markets in housing and housing assistance. AHURI Final Report No. 307, Melbourne: Australian Housing and Urban Research Institute Limited.

Shaw, J., \& Graham, M. (eds). (2017). Our digital rights to the city. Oxford: Meatspace Press.

Shaw, J. (2018). Platform real estate: theory and practice of new urban real estate markets. Urban Geography, doi:10.1080/02723638.2018.1524653.

Tan, S. U. (2017, May 24). Altus sees future in big data, demographics. Financial Review. Retrieved from https://www. afr.com/real-estate/altus-sees-future-of-property-in-big-data-demographics-20170523-gwbjks

Tan, S. U. (2018, August 23). Leaselnfo launches Australia's first Al lease management platform. Financial Review. Retrieved from https://www.commercialrealestate.com.au/news/leaseinfo-launches-australiasfirst-ai-lease-management-platform-57311/

Taylor, L., \& Richter, C. (2015). Big data and urban governance. In J. Gupta, K. Pfeffer, H. Verrest, \& M. RosTonen (eds), Geographies of urban governance; advanced theories methods and practices (pp. 175-191). Dordrecht: Springer.

Tenants Union. (2015). Response to: Security of tenure issues paper of the residential tenancies act review. Melbourne: Tenants Union of Victoria. Retrieved from https://www.tuv.org.au/articles/files/submissions/ 151223-TUV-RTA-Security\%20of\%20Tenure.pdf

Willingham, R. (2018, August 27). Victoria gets $\$ 2.86$ billion in 'outstanding deal' to privatise Land Titles and Registry office. $A B C$ News, Retrieved from https://www.abc.net.au/news/2018-08-27/victoria-privatisesits-land-titles-and-registry-office/10169056

\title{
Digital Housing and Renters: Disrupting the Australian Rental Bond System and Tenant Advocacy
}

\author{
Dallas Rogers (D), Jathan Sadowski $(\mathbb{D})$ and Sophia Maalsen
}

University of Sydney, Australia

\section{Introduction}

Increasingly more of the things we do with, and in, houses are being mediated and changed by digital technology. A burgeoning body of work has started to explore these technological transformations and the issues arising in various parts of the housing sector. The issues explored in this work present many challenges for tenant advocates in Australia. With these concerns in mind, in late 2018 we gathered together the key tenant advocate organisations from every state and territory in Australia for a one-day workshop on digital housing.

The aim of the workshop was two-fold; First, in the short-term the aim was to broaden and sharpen the focus of our own research by reality checking our academic analysis - some of which we present below - with frontline housing practitioners and tenant advocates. A second longer-term aim is to work with tenant advocates to develop responses to three of the more pressing ways that technology is changing landlord/tenant relations. These are: the way renters live in homes; the way properties are rented and managed; and the way real estate is traded and exchanged. We briefly outline each below.

We conclude this essay with one illustrative case of how tech companies are seeking to insert themselves into the rental housing system by asking the question: how is the rental bond system likely to be augmented by tech companies and digital platforms, and what will be the flow-on effect for formal tenant advocacy in Australia? This was an issue that emerged as a major topic of discussion in the workshop, yet has been little discussed in the academic literature. This case is important for housing advocacy because it shows that the technology is not the issue per se, but 
rather the issue is how technology is brought together with the long-standing capitalist and rentier logics within private property housing systems.

\section{Issue 1: The Way Renters Live in Homes}

Many people now live in homes filled with devices - such as virtual assistants and smart appliances - that are data collecting, Internet-connected, and automatically controlled (Nicholls, Strengers, \& Tirado, 2017). Reminiscent of the arguments behind the introduction of "labour-saving" devices in the post-war period (Rogers, 2017), these technological upgrades are meant to make our homes more comfortable and easier to manage, thus turning the dumb house into a smart home. Yet this is only one part of the socio-technical story. The smart home is also a 'surveilled' space. By sensing the environment, tracking our (inter)actions and analysing our behaviours and preferences, an ensemble of digital technologies have turned the home into a "data factory" (McGuirk, 2015, np; Sadowski, 2019b). Thus, "amplifying and accelerating" longstanding trends in domestic surveillance and discipline, enacted by third-parties like government agencies and insurance companies (Maalsen and Sadowski 2019).

In addition to the sharp rise in sharing rental housing with other people (Maalsen, 2019) which is itself often mediated by digital platforms (Maalsen, 2018) - we now also share our homes with digital technologies that are partly owned and controlled by their manufacturers. This presents a threat to rental tenants because the data that is collected by devices as tenants go about their daily homemaking practices can be accessed by third-parties such as landlords, increasing the power asymmetry and threatening tenants' rights (Sadowski, 2019a).

\section{Issue 2: The Way Properties are Rented and Managed}

The new suite of digital platforms, which offer services that facilitate the valuation, rental and exchange of real estate, have a clear lineage back to pre-internet real estate practices and mentalities in countries like Australia (Rogers, 2017). However, the recently formed, but already well funded, "real estate/financial/technology complex" (Shaw 2018) demonstrates that there is widespread, aggressive interest from investors in exploiting the potentials of digital disruption in the housing sector. Under the umbrella terms of PropTech and RealTech, these digital platforms are clustered around providing services aimed at different aspects and actors in the real estate market (Dal Maso, Robertson, \& Rogers, 2019; Shaw 2018).

Tenant advocates in Australia are looking at the global Prop/RealTech sector as a further, potential threat to rental tenants to come. For example, companies like Zillow (US) and Zoopla (UK) provide services to investors that include centralising detailed data about property from various sources, optimising decision-making with automated valuation models based on proprietary analytics, and mediating transactions by connecting buyers/investors/renters and sellers/owners (see Landau-Ward and Porter this issue). The "uploading" of private property real estate mentalities and practices into digital platforms is a problem for rental security (Rogers, 2017), wherein the ultimate goal is to facilitate the frictionless flow of capital into landed assets that are increasingly thought of as "digital, global commodit[ies]" (Rogers, 2016). 


\section{Issue 3: The Way Real Estate Is Traded and Exchanged}

At the convergence of smart homes and platform real estate emerges a new set of global rentiers, including the "global corporate landlords" (Beswick et al., 2016) and the global corporate land-less-lords. One variety of the global landlord is the private equity firms that own large investment portfolios containing thousands of rental properties, which are geographically spread across multiple cities, countries, and continents (Fields, 2018). The unique challenges posed by overseeing property portfolios and securitising rental income have given rise to "the automated landlord," as Desiree Fields calls it, "whereby the management of tenants and properties is increasingly not only mediated, but governed, by smartphones, digital platforms, and apps, and the data and analytics these devices and infrastructures gather and enable" (Fields, 2019, p. 4).

One variety of the global land-less-lord is Airbnb, which, while not owning much landed property, has emerged as a powerful global short-term rental landlord nonetheless. The digital, financial and technological innovations that underwrite these landlord practices are an obvious threat to rental tenants because they are creating new ways to extract the value from rental homes and to exploit the tenants who live in these assets.

With these three issues as the context, our final two sections explain how the rental bond system in Australia works and how tech companies are planning to change the system. This case shows that technological innovation is neither intrinsically positive or negative, rather it is the socio-technical arrangements within which the technology is produced and implemented that determines its social, economic, and political effects.

\section{Disrupting the Rental Bond System}

A rental bond is essentially a type of landlord insurance or guarantee that covers any potential damage to a property that is caused by a tenant, which goes beyond normal wear and tear. In the state of New South Wales (NSW), as in many Australian states and territories, a rental bond is collected from the tenant before they move into the property to the amount of no more than four weeks rent, although four weeks rent is a relatively standard bond amount. At the end of a tenant's lease, the property is inspected by the landlord or their agents, and if the property is deemed by the landlord/agents to be in a reasonable state, the bond is refunded to the tenant in full.

There are well reported issues with this rental bond system. For example, for people on low incomes, and, increasingly, for moderate income-earners, a lump sum bond payment of four weeks rent is often a financial burden during the rental application process. The government recognises this, and low-income earners can apply for 'Rentstart' assistance through their local Housing NSW Office, and a bond can also be lodged in instalments. Furthermore, a lack of transparency and power asymmetry between tenants and landlords within the everyday management of the rental bond system has allowed unscrupulous landlords/agents to withhold or delay the return of a bond.

In response to these and other inefficiencies and inequities in the rental bond process, in 2015 the NSW Government's Office of Fair Trading introduced the first digital disruption to the rental bond system with the launch of their Rental Bonds Online technology: a digital portal that allows tenants, landlords, and agents to lodge rental bonds online. The Rental Bonds Online system streamlined the bond lodgement and return process, therein circumventing the need for the middleman (e.g., landlord/agent). The system mitigates some of the flaws in the previous system by preventing landlords/agents from delaying or denying the return of the bond. 
When a bond is lodged by a tenant it is held in trust by The Rental Board, an NSW state government agency tasked with holding rental bonds paid by tenants to landlords for residential tenancies. This bond trust system is important for tenant advocacy in NSW because the interest generated from the bonds held in trust by The Rental Board - along with the Property Services Interest Account which holds interest earned on rent and deposits - is used to fund tenant advocacy services. ${ }^{2}$ Tech companies are looking to enter this rental bond system, gain access to the capital that is held in trust, and put this capital to use in other ways.

\section{Disrupting Tenant Advocacy}

The attempted entry of tech companies into the bond space represents the next wave of digital disruption to the rental bond system. There are a growing number of rental bond tech start-ups essentially bond insurance companies - that are offering supposedly 'cheaper' alternatives to tenants. The bond insurance companies allow tenants to pay a fee for a bond surety certificate that costs less than the four weeks rent they would have to pay otherwise. If a claim is made by the landlord/agent when the tenant exits their lease, the bond insurance company provides a guarantee to pay the landlord's claim. This may seem like a reasonable service to provide for both tenants and landlords, but as our tenant advocate partners told us in our workshop, the devil is in the technological and financial details of this privatised bond insurance system.

One of these tech start-ups, Snug, argues that this puts the money back in the tenants' hands instead of sitting and accumulating interest in the Rental Bond Board (Snug, n.d.). By paying a surety fee instead of cash bond, Snug argues, tenants can invest that money or spend it on unexpected expenses or return it to the economy. However, as our tenant advocate partners argue, the design of the current Rental Bond Board system allows the interest generated from the private property rental system to be directed into government services that provide support to tenants (TUNSW, 2018). The tech start-up model of rental bond insurance would undermine this system. In this disrupted model, private sector companies would gain access to bond fees that are paid by tenants - transferring the control and benefits of bond capital from public to private coffers - thus, depriving the tenant advocates of the funding for their services (TUNSW, 2018). As Leo Patterson Ross (2018) of the Tenants Union of NSW argues,

"In Australia, tenancy disruptors like TrustBond, Snug, and others try and present as being for tenants, but I believe they realised that the power rests heavily with the service provider and since they don't have a plan to disrupt the physical supply of rental housing, they have sought to either reduce service provider costs without any benefit flowing to end user or eke out essentially private taxes from end users. This is particularly been the case with alternative bond loan products which claim to replace cash bond but actually protect current landlord interests by maintaining their current costs and risk profile, while extracting a fee from the end user tenant to access the product."

In conclusion, as with so much digital disruption, the essential dynamics at work follow a familiar story of power asymmetries, capital accumulation, and private hands grabbing public value. That is not to say the technologies and their outcomes are pre-determined, but rather that they are highly dependent on the political, economic, and social context within which these technologies are created and implemented. In short, the question is: who is disrupting whom?

To begin to answer this question, we have outlined three key ways housing is being digitally disrupted: 1) the way renters live in homes; 2) the way properties are rented and managed; and 3) the way real estate is traded and exchanged. But an important lesson from our research and engagement 
is that scholars need to work closely with tenant advocates to both test their ideas and approaches, and to develop responses to the digital housing challenges already coming over the horizon.

\section{Notes on contributors}

Dallas Rogers is a senior lecturer in the School of Architecture, Design and Planning at the University of Sydney. His work focuses on cultures and histories of land, housing and urban governance. Email: Dallas.rogers@sydney.edu.au

Jathan Sadowski is a postdoctoral research fellow in smart cities in the School of Architecture, Design, and Planning at the University of Sydney. His book - Too Smart: How Digital Capitalism is Extracting Data, Controlling Our Lives, and Taking Over the World - will be published in 2020 by The MIT Press. Email: Jathan.sadowski@sydney.edu.au

Sophia Maalsen is a lecturer in the School of Architecture, Design and Planning at the University of Sydney. Her work focuses on the digital disruptions of cities, gender, housing and home. Email: Sophia.maalsen@sydney.edu.au

\section{ORCID}

Dallas Rogers (D) http://orcid.org/0000-0002-9359-8958

Jathan Sadowski (D) http://orcid.org/0000-0002-3184-384X

\section{References}

Beswick, J., Alexandr, G., Byrne, M., Vives-Miró, S., Fields, D., Hodkinson, S., \& Janoschka, M. (2016). Speculating on London's housing future: The rise of global corporate landlords in 'post-crisis' urban landscapes. City, 20(2), 321-341.

Dal Maso, G., Robertson, S., \& Rogers, D. (2019). Cultural platform capitalism: Extracting value from cultural asymmetries in RealTech. Social and Cultural Geography. doi:10.1080/14649365.2019.1601246.

Fields, D. (2018). Constructing a new asset class: Property-led financial accumulation after the crisis. Economic Geography, 94(2), 118-140.

Fields, D. (2019). The automated landlord: Digital technologies and post-crisis financial accumulation. Environment and Planning A: Economy and Space. doi:10.1177/0308518X19846514.

Maalsen, S. (2018). 'Generation Share': Digitalized geographies of shared housing. Social \& Cultural Geography, doi:10.1080/14649365.2018.1466355.

Maalsen, S. (2019). I cannot afford to live alone in this city and I enjoy the company of others: Why people are share housing in Sydney. Australian Geographer, 50, 315-332.

Maalsen, S., \& Sadowski, J. (2019). The smart home on FIRE: Amplifying and accelerating domestic surveillance. Surveillance \& Society, 17(1/2), 118-124.

McGuirk, J. (2015). Honeywell, I'm Home! The internet of things and the new domestic landscape. E-Flux, 64. Retrieved from https://www.e-flux.com/journal/64/60855/honeywell-i-m-home-the-internet-of-thingsand-the-new-domestic-landscape/

Nicholls, L., Strengers, Y., \& Tirado, S. (2017). Smart home control: Exploring the potential for enabling technologies in households. Melbourne: Palgrave Macmillan.

Rogers, D. (2016). Uploading real estate. In N. Cook, A. Davison, \& L. Crabtree, (eds.), Housing and home unbound: Intersections in economics, environment and politics in Australia (pp.23-38). Melbourne: Routledge. 
Rogers, D. (2017). The Geopolitics Of Real Estate: Reconfiguring property, capital and rights. London: Rowman and Littlefield International.

Ross, L. P. (2018, December 7). Disrupt landlords. The Tenants Union of NSW Blog. https://tunswblog. blogspot.com/2018/12/disrupt-landlords.html

Sadowski, J. (2019a, 6 June). Privacy is just the beginning of the debate over tech. OneZero. Retrieved from https://onezero.medium.com/privacy-is-just-the-beginning-of-the-debate-over-tech-8807c2f8458f

Sadowski, J. (2019b). When data is capital: Datafication, accumulation, extraction. Big Data \& Society, 6 (1), $1-12$.

Shaw, J. (2018). Platform real estate: Theory and practice of new urban real estate markets. Urban Geography. doi:10.1080/02723638.2018.1524653

Snug. (n.d.). Help return $\$ 1.4$ billion of bonds to NSW renters. Retrieved from https://snug.com/better bonds/nsw/

TUNSW. (2018). The bond is too damn high. The Tenants Union of NSW Blog. Retrieved from http:// tunswblog.blogspot.com/2018/05/the-bond-is-too-damn-high.html

\section{Prospects for an Intelligent Planning System}

Rob Kitchin ${ }^{a}$, Oliver Dawkins ${ }^{b}$ and Gareth Young ${ }^{b}$

${ }^{a}$ Maynooth University Social Sciences Institute and Department of Geography, Maynooth University, County Kildare,

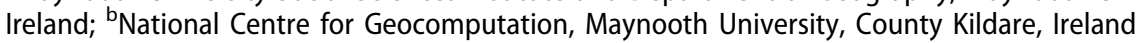

\section{A Computational Approach to Planning}

The creation of an intelligent planning system that draws together all the data for a city and uses these, in combination with the algorithmic encoding of planning policy and law, to automate the production of optimal strategic plans and recommendations for rational planning decisions, has long been an ambition for a subset of planners and urban policy-makers. Writing in 1965, Melvin Webber proposed the creation of intelligence centres that would collate and interlink data, supply analysis and forecasts, formulate strategic plans, aid incremental, multicentered decision-making, and enact a scientific morality in urban affairs. An intelligent planning system, he hypothesised, would tackle subjective opinion, clientelism and vested interests, learn from its actions, be more efficient, and lead to more effective outcomes (Webber, 1965).

In 1969, Jay Forrester set out a cybernetic approach to planning and cast the city as a system of systems. Each system, Forrester (1969) postulated, could be broken into its constituent parts and processes, be modelled and simulated to capture its essence, and these models used to plan and operate its functions. In the 1970s, the systems perspective cast planning as an evidence-informed, structured, rational, applied science that could be performed computationally. In the 1980s and 90s, GIS became a platform for drawing together and analysing spatial data and creating spatial planning intelligence about places. GISs were complemented by spatial decision support systems and expert systems that encoded planning rules and practices and could guide decision-making (Kim, Wiggins, \& Wright, 1990; Klosterman, 1997). This was accompanied in the 1990s by initial experimentation with 3D urban and landscape models, and virtual reality (VR) technologies that could convey the topography of existing and planned future environments (Doyle, Dodge, \& Smith, 1998).

Cybernetic thinking re-emerged in the 2000s with the growth in big data - real-time data concerning a system's performance - and more advanced computation, including artificial intelligence (Krivỳ, 2018). Intelligent transport systems such as road traffic control became 
increasingly automated, with real-time data from sensors, inductive loops and cameras being used to automatically adjust the phasing of traffic light sequences, but also to underpin transport modelling and simulation to increase operational efficiencies and inform infrastructure planning at a strategic level (Coletta \& Kitchin, 2016). This has been accompanied by open data initiatives to make urban data more widely available, urban dashboards that provide public tools for making sense of such data (Kitchin, Lauriault, \& McArdle, 2015), and a plethora of applied urban informatics and urban science projects and apps (Batty, 2013). In some cities there are initiatives to create intelligent operations centres: facilities in which several systems and their data are integrated into a single control room to enable a more holistic view of city services and infrastructures. For example, the Centro De Operacoes Prefeitura Do Rio in Rio de Janeiro, Brazil, draws together administrative, statistical and real-time data from thirty two agencies and twelve private concessions (e.g., bus and electricity companies) in order to manage day-to-day operations and plan the city (Luque-Ayala \& Marvin, 2016).

3D technologies, such as 3D GIS, BIM (Building Information Modelling) and CIM (City Information Modelling) are increasingly being explored as platforms for creating and utilising spatial intelligence for urban design and planning. BIM enables the full build cycle for a project to be viewed and queried within one system, including a detailed, interactive 3D model (rather than hundreds of 2D plans, sections, and elevations), and allows users to dynamically update and recalculate scheduling and quantities of materials with changes in design or specifications (Crotty, 2011). CIM extends that idea to the city level by creating a 3D city model populated with associated data and enhanced with analytic tools that enable the examination of spatial relationships, and the simulation of urban processes under different conditions, to facilitate informed decision-making concerning city management and planning (Thompson, Greenhalgh, Muldoon-Smith, Charlton, \& Dolník, 2016). More recent efforts are rallying around the concept of Digital Twin - digital representations of assets, processes or systems in the built or natural environment - which is now being championed in the UK as a new means of managing urban systems and infrastructures throughout their lifetime (Bolton, Enzer, \& Schooling et al., 2018).

Our own work on the Building City Dashboards ${ }^{3}$ project is charged with creating a set of open spatial technologies that can help support planning functions in Dublin and Cork. Conducted in partnership with the four Dublin local authorities and two Cork authorities, plus the Central Statistics Office and Ordnance Survey Ireland, the aim is to assemble as much longitudinal data about the city as possible, preferably with a sub-county granularity and less than yearly. An associated set of tools will be provided including urban dashboards designed to be accessible for users with different levels of data and statistical literacy (general public, policymaker, professional analyst), and incorporating data stories (narrative richly supported by data visualisations), task-based tools (interactive visualisations), and analytical tools (statistical analysis, predictive models and simulations) ${ }^{4}$; a prototype planning-orientated CIM supporting desktop, augmented reality (Hololens) and VR (Vive, Occulus) applications; projection mapping data onto a 3D physical architectural model of the city; and mobile apps. A significant component of the project is to determine a set of principles and guidelines for the production of these systems, and to examine in detail the politics and limitations in their creation and use (Kitchin et al., 2015). 


\section{Challenges in Creating an Intelligent Planning System}

Despite the development of, and significant investment in, planning-related digital technologies - and more broadly big data and artificial intelligence - their use is constrained within planning systems worldwide and the dream of an intelligent planning system remains unfulfilled. While GIS is well embedded as a supporting technology for regional and urban scale planning, and BIM is being mainstreamed in the Global North for the design and management of larger architectural, engineering and construction projects, other planning-related digital technologies are used only partially or remain in an experimental phase. Moreover, much of the planning profession is wary of a computational, technocratic approach to planning practice. As such, the prospects for the creation and mainstreaming of a holistic intelligent planning system remain problematic. The challenges stymying such a vision are two-fold: technical, and institutional and political.

\section{Technical Challenges}

Producing an intelligent planning system is not a trivial task. As noted, the technologies discussed above have been in development for decades. GISs have continually evolved since the 1960s and only became adopted for mainstream use in the 1990s. There have been prototype 3D technologies for close to thirty years, yet it is only recently that they are starting to be used in professional planning, mostly on a trial basis. CIMs are still in the early phases of development and, from our own experiences of trying to develop one, they continue to pose significant challenges. On the one hand, these challenges are software related, requiring the use and integration of different platforms and packages that each have their limitations, often necessitating the development of new workflows and the creation of bespoke code to bridge shortcomings. This has been a significant challenge in our work, since there are as yet no fully functioning open source solutions for the creation of CIMs, and the gameengine visualisation software used for optimally displaying 3D environments is not generally configured to be used like a 3D GIS (using different coordinate systems and often lacking the required spatial precision, for example). In addition, artificial intelligence systems for planning are still in their infancy and require substantial development to reach sufficient maturity and trust to underpin intelligent decision-making. Again, we are having to build and experiment with analytic predictive modelling and simulation tools rather than using established off-the-shelf products.

On the other hand, there are still significant issues with respect to data. Detailed, up-to-date and well maintained 3D models of landscapes are still relatively uncommon. More generally, there are ongoing issues of access, coverage, representativeness, quality, completeness and metadata with respect to urban data. Indeed, our work has highlighted just how difficult it is to assemble relevant, timely, granular, high quality, interoperable datasets. We have struggled to gain access to some data, have very little metadata concerning data provenance and quality, and lack methodological transparency regarding the data we can access. We also have to perform significant data wrangling to create workable and meaningful datasets (McArdle \& Kitchin, 2016). As a result, there are significant gaps in our attempts to produce digital representations for each city, and what data we have assembled is often far from ideal. This situation is unlikely to alter much in the mid-to-long term without a major change in the data regimes of city administrations.

\section{Institutional and Political Challenges}

When proposing an intelligence approach to planning, Melvin Webber was also mindful of the institutional and political aspects of planning and that cities and regions are complex entities that 
cannot be simply reduced into data and rules and run via computational, technocratic procedures. Planning is inherently political. Cities and regions are full of competing vested interests, and decisionmaking is the art of making compromises. Webber's proposal was to improve the quality of decisions and actions through the creation of intelligence centres, while being mindful of the politics of information and the politics of planning itself. As our own work testifies, there is significant internal and inter-institutional politics and negotiation involved in creating and operating urban dashboards, which inevitably shape the systems developed and what they convey (Kitchin, Maalsen, \& McArdle, 2016). Planning technologies and their operation are never neutral, value-free enterprises.

A significant challenge in creating an intelligent planning system is to harness the power of data and computation while ensuring the treatment of cities as places, not merely systems. This requires being open to public opinion, debate, and contestation rather than enacting an autonomous technocratic approach. It also requires a methodological approach that is open and transparent, qualities that systems employing artificial intelligence struggle with, as analysis of the ethics of smart city technologies highlight (Kitchin, 2016). Moreover, the professional planning community has long held concerns with regards to technocratic and computational approaches to planning (see Flood, 2011), and has sought to pursue other forms of planning practice that use different epistemological and methodological approaches, promoting a different planning ethos and values (see Gunder, Madanipour, \& Watson, 2016). In interviews with senior planners in Ireland about the potential use of CIMs in planning, our interviewees, while noting the potential benefits of such technology, expressed a number of doubts and concerns with respect to its utility in aiding planning praxes. All held the view that they would be supporting aids rather than a vital component of decision-making. A major shift in planning theory, ideology and practice will need to occur for an intelligent planning system approach to become common-place. There is little evidence that such a shift is likely in the short-to-mid term.

\section{Conclusion}

There is little doubt that much more data is becoming available that might aid planners in the formulation and assessment of plans. There are also a growing range of technical systems that provide ever more sophisticated supports for data-driven analysis. However, the prospects of creating and mainstreaming a holistic, intelligent planning system seem remote, due to challenges of a technical, institutional and political nature. That is not to say, however, that digital technologies utilising big data and artificial intelligence will remain on the sidelines of planning practice. As technologies mature and become more sophisticated their utility will be exploited to aid design and assessment. Such use raises questions about the nature of planning and the extent to which an already technocratic profession should become computationally codified and automated. These questions will become more pressing as the political pressure intensifies to adopt such technologies as part of a move towards the creation of smart cities (Kitchin 2014). It is necessary then for planners to proactively formulate how such technologies should fit within the planning system, how the planning system fits within smart cities, and how their own processes might change to accommodate these shifts, rather than letting external forces and the technologies dictate future vision, habitus and practices.

\section{Funding}

The research for this paper was funded by Science Foundation Ireland, grant number [15/IA/3090]. 


\section{Notes on contributors}

Rob Kitchin is a Professor in the Department of Geography and Maynooth University Social Sciences Institute. He was principal investigator on the Programmable City project and is presently a co-PI on the Building City Dashboards project funded by Science Foundation Ireland. Email: Rob.kitchin@mu.ie

Oliver Dawkins is a researcher in the National Centre for Geocomputation at Maynooth University working on the Building City Dashboards project and a PhD student at the Centre for Advanced Spatial Analysis at University College London. Email: oliver.dawkins@mu.ie

Gareth Young is a postdoctoral research fellow in the National Centre for Geocomputation at Maynooth University working on the Building City Dashboards project and is interested in human-computer interaction and user-centred design. Email: Gareth.Young@mu.ie

\section{References}

Batty, M. (2013). The new science of cities. Cambridge, MA: MIT Press.

Bolton, A., Butler, L., Dabson, I., Enzer,M., Evans, M., Fenemore, T., ... Makri, C. (2018). The Gemini principles: Guiding values for the national digital twin and information management framework. Cambridge: Centre for Digital Built Britain and Digital Framework Task Group.

Coletta, C., \& Kitchin, R. (2016). Algorhythmic governance: Regulating the 'heartbeat' of a city using the Internet of Things. Big Data and Society, 4, 1-16.

Crotty, R. (2011). The impact of building information modelling: Transforming construction. London: Routledge.

Doyle, S., Dodge, M., \& Smith, A. (1998). The potential of web-based mapping and virtual reality technologies for modelling urban environments. Computers, Environment and Urban Systems, 22(2), 137-155.

Flood, J. (2011). The fires: How a computer formula, big ideas, and the best of intentions burned down New York City and determined the future of cities. New York: Riverhead.

Forrester, J. W. (1969). Urban dynamics. Cambridge, MA: MIT Press.

Gunder, M., Madanipour, A., \& Watson, V. (2016). The Routledge handbook of planning theory. London: Routledge.

Kim, T. J., Wiggins, L. L., \& Wright, J. R. (1990). Expert systems: Applications to urban planning. New York: Springer-Verlag.

Kitchin, R. (2014). The real-time city? Big data and smart urbanism. GeoJournal, 79(1), 1-14.

Kitchin, R. (2016). The ethics of smart cities and urban science. Philosophical Transactions A, 374(2083), 1-15

Kitchin, R., Lauriault, T., \& McArdle, G. (2015). Knowing and governing cities through urban indicators, city benchmarking and real-time dashboards. Regional Studies, Regional Science, 2, 6-28.

Kitchin, R., Maalsen, S., \& McArdle, G. (2016). The praxis and politics of building urban dashboards. Geoforum, 77, 93-101.

Klosterman, R. E. (1997). Planning support systems: A new perspective on computer-aided planning. Journal of Planning Education and Research, 17, 45-54.

Krivỳ, M. (2018). Towards a critique of cybernetic urbanism: The smart city and the society of control. Planning Theory, 17(1), 8-30.

Luque-Ayala, A., \& Marvin, S. (2016). The maintenance of urban circulation: an operational logic of infrastructural control. Environment and Planning D: Society and Space, 34(2), 191-208.

McArdle, G., \& Kitchin, R. (2016). Improving the veracity of open and real-time urban data. Built Environment, 42(3), 457-473.

Thompson, E. M., Greenhalgh, P., Muldoon-Smith, K., Charlton, J., \& Dolník, M. (2016). Planners in the future city: Using city information modelling to support planners as market actors. Urban Planning, 1(1), 79-94.

Webber, M. (1965). The roles of intelligence systems in urban-systems planning. Journal of the American Institute of Planners, 31(4), 289-296 


\section{What are the Prospects for a Politically Intelligent Planning System?}

Lisa K. Bates

Toulan School of Urban Studies and Planning, Portland State University, Portland, Oregon, U.S.

In "Prospects for an Intelligent Planning System," Kitchin, Dawkins, and Young (this issue) describe a tantalizing vision for the modern urban planner - complete, longitudinal and spatial urban data in a Geographic Information System with enough computational power to generate predicted outcomes for regulations, investments, and development. I've spent my research and practice career thinking about how neighborhood housing markets change in response to planning and policy interventions, and have often wished to be able to demonstrate exactly how a city's choices about urban regeneration will play out over space and time, and to forewarn planners about unintended consequences like displacement. Looking backwards, it's easy to analyze the effects of our choices but we plan for the future, and wish for our data systems to support decisions.

My colleagues rightly list problems with data access and quality and the politics and institutions of planning as barriers to intelligent planning systems. In this short paper, I will describe how these challenges play out in my own research and practice consultancy work in Portland, Oregon. I attempt to take a data-driven approach to gentrification and housing displacement, trying to predict the effects of new bus rapid transit and light rail lines in racially diverse, lowerincome neighborhoods. Will new service support communities have greater mobility, or will they lose out when they are displaced by higher-income residents as their neighborhoods gain access? My analyses focus on whether owners raise rents, convert units into higher-end housing, or sell to owner-occupants as transit changes the desirability of neighborhoods, and where lowincome residents might move if they are displaced.

Planning agencies in our region have significant modeling capacities and are known for coordinating land use and transportation systems data and innovating in 'big data' planning. By contrast, I have found significant barriers in availability and access to housing data, and methodological issues with the use of housing data in urban systems models. These problems with our 'smart cities' planning consistently and systematically undercount or miscount the people who are most vulnerable to urban change - low-income households, people of color, and renters.

Obviously the first step towards an intelligent planning system for understanding the housing market implications of policy, is a dataset with a count of units, their price and quality. However, data that comprehensively covers housing, especially rental housing, are not available in the Portland region. That there are significant missing components of these datasets is not due to the capacity to collect or store data, but due to political and market features of a system that relies on private actors to provide housing.

\section{Limited Data Leads to Limited Analysis}

The rental market includes both large multifamily buildings that are categorized as commercial residential properties, and a stock of single family, duplex- triplex- and quadplex- dwellings. In the United States, about $40 \%$ of the rental housing stock is single-family homes, and another $10 \%$ is small, two to four unit structures, rather than apartment buildings (Joint Center for Housing Studies, 2016). Many of these small units are owned by individual, 'Mom-and-Pop' 
landlords. According to the 2010 decennial census, 58\% of rental units along the planned express bus corridor are single family houses (Bates, Golub, MacArthur and Sung, 2017). An up-to-date count of these units to add to the 'big data' on the city doesn't exist, since Portland has not required registration of rental units with the city and has no housing census (Hammond, 2018). There is no historical data to analyze for patterns about how rents have been set and changed in response to new transit access. Planners asked important questions about how infrastructure might lead to displacement, but a model that cannot represent more than half of housing units is not a viable decision tool.

Data about the rest of the rental housing market - units in large multifamily properties - do exist and could be analyzed, were they freely available to public sector planners. In this segment of the market data exist, but behind paywalls and license agreements, serving the interests of private market actors. The City's staff has limited access to proprietary, commercial real estate databases, the privately-owned sources of detailed information routinely used by development professionals. As a university-based researcher, I've been able to access some additional information from data sources licensed for research use - although without nearly the level of historical detail nor real-time updating that a full-price license would provide. Our analysis of disaggregated data does show that housing supply is only sufficient at the highest prices (Sung \& Bates, 2017).

Collaborating with planning agency modelers further demonstrated how pronounced the limits in data systems are for understanding the equity implications of urban change. We wanted to build a model of how greenhouse gas emissions would be affected by the new transit lines, incorporating the probability that some or many households would be displaced. Fitting together the transportation and environmental data with the already flawed housing data, involved imputations, aggregations, and assumptions that all tended to flatten detail about low-income renter households. I could not maintain distinctions of income levels that are relevant for housing access. While race remains an important driver of housing access and choice, and relates strongly to household formation and size in our region, the transportation and population projection models used do not account for race or ethnicity. Low-income households of color, who are more likely to be both precariously housed and transit-dependent than white low-income households, could not be represented as a group for whom outcomes should be assessed distinctly.

\section{Resources and Politics Determine Data Availability}

Certainly, there would be a cost to creating housing registries and data systems, but it is not only the inertia of bureaucracy that prevents the development of these data. Portland and Oregon have been debating laws to regulate tenant application screening practices, limit eviction, ensure quality and health standards, and cap rent increases, with loud objections from the owners of real estate. 'Mom-and-Pop' landlords have sought and won exemptions from tenant protections and housing inspections, and argue that compliance with any additional regulation is an undue burden on them. Without any solid data on the small rental unit stock, arguments about policies have occurred in the rhetorical realm, not in a rational planning process, with landlords claiming steep losses and threatening to withdraw units from the market (VanderHart, 2018). The data blind spot has made it possible for those 
providing a large proportion of rental housing to block policies that could support vulnerable tenants, and to evade accounting of health standards violations. ${ }^{5}$

Where data exist, they are often not accessible. With pay-by-the-desktop pricing, staff at the City are limited to using commercial real estate databases only in some departments, at the desks of a few planning analysts who were given system logons. The commercial databases are very expensive; it is also frustrating as an advocate for better housing planning that the public sector does not make greater efforts and resources available for assembling housing data, given the push for 'big data' in planning. I've argued that U.S. planners have ceded far too much to the private sector in our regulation of housing development, weighing the interests of real estate capital markets over those of community members (Bates, 2012). When planners are working with incomplete or out of date housing market data, we can't produce a full analysis of the distribution of benefits and burdens of development policies. Meanwhile private, for-profit real estate professionals create their own analyses, which are not transparent to the public practitioners, in their advocacy. The developer lobby has been fighting against Portland's requirement that new buildings must include low-cost units, arguing that the policy is shutting down the development pipeline, using these proprietary data. In Portland's planning discussion about addressing our housing affordability crisis, developers and investors wield their proprietary data to argue against any regulatory change. Without robust public data, both planners and community advocates are on the back foot in policymaking debates.

\section{Can We Model Out of the Status Quo?}

Portland's regional systems modeling forms the fact base from which planning decisions are made, but the housing data in these computations are deeply flawed. We are simply missing information about a substantial portion of the market that serves low-income people; and we have limited access to data that are used to reinforce market narratives about planning. If we continue to build planning analysis systems from these bases, we will not have sufficient information to understand the housing choices and constraints of low-income people, renters, and communities of color. These groups experience displacement due to gentrification, transit dependency in locations that are under-served, and the health consequences of environmental problem hotspots, all of which should be core concerns for planners. However, the data systems available and the modeling methods used don't reveal the extent of housing problems in our region or how policy may exacerbate inequalities. Planners may be able to make better policies with more equitable outcomes with more complete data and analysis, but housing market actors who prefer the status quo have an interest in limiting data collection and access. If we hope to plan better to avoid displacement effects of infrastructure investment, we need to recognize that data and models are as political as any other part of the planning process. Despite technological advances only dreamed of by our planner forebears, institutional and political barriers still leave urban models inadequate to the task of addressing some of our most pressing urban challenges. If planners want to bring sophisticated analytics to bear, we must first confront the interests who would prefer to maintain control over the visibility of their activities. 


\section{Notes on contributor}

Lisa K. Bates is Associate Professor in the Toulan School of Urban Studies and Planning at Portland State University. Her research and practice as a planner address housing and neighbourhood change, with a focus on more just outcomes. Email: Lkb.pdx@gmail.com

\section{References}

Bates, L. K. (2012). Housing: Planning and policy challenges. In R. Crane \& R. Weber (Eds.), The Oxford handbook of urban planning. New York, NY: Oxford University Press.

Bates, L. K., Golub, A., MacArthur, D., \& Sung, S. (2017). Planning ahead for livable communities along the powell-division BRT: Neighborhood conditions and change. (Report No. NITC-RR-912), Portland, OR: Transportation Research and Education Center, Portland State University. doi:10.15760/trec.179

Hammond, B. (2018, July 26). Portland will require all landlords to register their apartments - by late 2020. The Oregonian, Retrieved from https://www.oregonlive.com

Joint Center for Housing Studies (JCHS). (2016). State of the Nation's Housing 2016. Cambridge, MA: Harvard University. Retrieved from https://www.jchs.harvard.edu//research-areas/reports/state-nationshousing-2016.

Sung, S., \& Bates, L. K. (2017). Preserving Housing Choice and Opportunity: A Study of Apartment Building Sales and Rents (Report). Portland, OR: Center for Urban Studies, Portland State University. doi:10.15760/ report-02

VanderHart, D. (2018, January 24). Portland's small-time landlords don't have to follow renter protections. Portland Mercury. Retrieved from https://www.portlandmercury.com.

\section{Notes}

1. Defined in terms of race, color, religion, national origin, sex, disability, and familial status.

2. Although, it is worth noting that funding for tenant advocacy services has not been increased since 2004. With inflation, this stagnation is a steady decrease in real funding.

3. http://dashboards.maynoothuniversity.ie/.

4. http://www.dublindashboard.ie and http://www.corkdashboard.ie.

5. Attempting a census of housing that will provide baseline information for policy analysis, Portland will finally require rental unit registration in 2020 - with minimal information and no required inspection.

Join in the debate on Twitter \#PTPInterface 